\title{
PERAN BRAND IMAGE MEMEDIASI PENGARUH SOCIAL MEDIA MARKETING TERHADAP REPEAT PURCHASE
}

\section{Ni Luh Widya Uttari ${ }^{1}$ I Gusti Ayu Ketut Giantari ${ }^{2}$}

Article history:

Submitted:

18 Februari 2022

Revised:

26 Februari 2022

Accepted:

26 Februari 2022

\section{Keywords:}

Brand Image;

Social Media Marketing;

Repeat Purchase.

\section{Kata Kunci:}

Citra Merek;

Pemasaran Media Sosial;

Pembelian Berulang.

\section{Koresponding:}

Fakultas Ekonomi dan Bisnis Universitas Udayana, Bali, Indonesia

Email:

niluhwidyauttari@gmail.com

\section{Abstract}

The purpose of this study was to explain the role of brand image in mediating the influence of social media marketing on repeat purchases of Mie Gacoan customers in Denpasar City. The sample used in this study was 130 respondents using a questionnaire with google form. The method of determining the sample using purposive sampling method with PLS-based SEM analysis technique. The results show that, social media marketing has a positive and significant effect on repeat purchases, social media marketing has a positive and significant effect on brand image, brand image has a positive and significant effect on repeat purchases, brand image is significantly positive and significant is able to mediate the influence of social media marketing on repeat purchases. Based on the results of this study, Mie Gacoan in Denpasar City has done social media marketing well, so that it has a good brand image to increase repeat purchases.

\begin{tabular}{l} 
Abstrak \\
\hline Tujuan Penelitian ini adalah untuk menjelaskan peran brand image \\
memediasi pengaruh social media marketing terhadap repeat purchase pada \\
pelanggan Mie Gacoan di Kota Denpasar. Sample yang digunakan pada \\
penelitian ini sebanyak 130 reponden dengan menggunakan kuesioner \\
berupa google form. Metode penentuan sampel menggunakan metode \\
purposive sampling dengan teknik analisis SEM berbasis PLS. Hasil \\
penelitian menunjukkan bahwa, social media marketing berpengaruh secara \\
positif dan signifikan terhadap repeat purchase, social media marketing \\
berpengaruh secara positif dan signifikan terhadap brand image, brand \\
image berpengaruh secara positif dan signifikan terhadap repeat purchase, \\
brand image secara positif dan signifikan mampu memediasi pengaruh \\
social media marketing terhadap repeat purchase. Berdasarkan hasil \\
penelitian ini Mie Gacoan di Kota Denpasar telah melakukan social media \\
marketing dengan baik, sehingga memiliki brand image yang baik untuk \\
meningkatkan repeat purchase.
\end{tabular}

Fakultas Ekonomi dan Bisnis Universitas Udayana, Bali, Indonesia ${ }^{2}$ 


\section{PENDAHULUAN}

Adanya pandemi COVID-19 memberikan dampak disegala aspek kehidupan, salah satunya pada bidang ekonomi. Pelaku usaha dituntut mampu menyesuaikan diri untuk bisa memanfaatkan teknologi yang ada untuk mempromosikan produk yang dimiliki (Khasanah et al., 2020). Dampak dari adanya pandemi COVID-19 mengakibatkan terjadinya perubahan serta pergeseran pola perilaku pembelian konsumen. Sebelum adanya pandemi, belanja online memang sudah mulai diminati. Namun, tidak sedikit konsumen untuk tetap datang langsung ke toko untuk melihat dan mencoba secara langsung produk yang ingin dibelinya (Hardilawati, 2020).

Provinsi Bali juga merasakan dampak yang diakibatkan dengan adanya COVID-19. Banyak pekerja dibidang pariwisata kehilangan pekerjaannya dan terpaksa dirumahkan. Para pekerja tersebut banyak yang mulai beralih profesi menjadi pedagang online. Mulai dari makanan, kebutuhan pokok, fesyen, dan produk lainnya mulai dijual atau dijajakan secara online. Promosi melalui sosial media menjadi pilihan utama untuk mempromosikan produk yang ditawarkan. Social media sangat membantu dalam meningkatkan penjualan secara online (Pratiwi, 2021). Saat ini belanja melalui sosial media ataupun e-commerce sangat digandrungi oleh masyarakat. Kemudahan belanja online konsumen tidak harus datang kangsung ke took dan juga tidak merasa sulit lagi untuk mendapatkan barang yang diinginkan. Cukup dengan memilih gambar yang tersedia di Akun toko online Instagram dan memesannya secara langsung, membayar dengan membayar melalui online, dan produk yang dipesan dikirim segera ke alamat pembeli (Nurlaily et al., 2017).

Salah satu produk yang banyak dijual secara online adalah produk makanan. Selama pandemi konsumen banyak melakukan pemesanan produk makanan baik melalui layanan pesan antar atau membeli langsung ke Restoran. Adanya pandemi COVID-19 tidak turut untuk menurunkan tren berbelanja produk kuliner pada masyarakat. Sebesar 87 persen pengguna internet di Indonesia telah melakukan pembelian secara online melalui perangkat elektronik masing-masing. Hal tersebut disampaikan oleh Hootsuite dan We Are Social dalam laporan yang berjudul Digital 2021. Berdasarkan hasil survei tersebut produk makanan berada diperingkat pertama produk yang dibeli secara online, selain itu ada produk perawatan pribadi, kecantikan, fesyen, video game, barang elektronik funitur, dan lain-lain (Kurniawan, 2021). Salah satu tempat makan favorit di Bali yang wajib dikunjungi dan direkomendasikan oleh IDN Times adalah Mie Gacoan (Azryantiti, 2019).

Mie Gacoan merupakan jaringan restoran mie pedas di Indonesia sejak tahun 2016, yang merupakan anak perusahaan PT Pesta Pora Abadi. Mie Gacoan menjual berbagai produk makanan seperti Mie dengan level kepedasan tertentu, Dimsum, dan minuman yang beraneka ragam. Keberadaan Mie Gacoan telah menerima tanggapan baik dari para konsumennya. Hal ini dapat dilihat dari google rating reviews yang dimiliki oleh ke empat cabang Mie Gacoan di Denpasar yakni 4,35 dari total 5 bintang. Dan untuk 
akun Instagram memiliki followers lebih dari 24,4 ribu akun Instagram. Strategi yang diterapkan oleh Mie Gacoan adalah dengan memberikan give away dan diskon untuk mempertahankan loyalitas konsumen dan menarik perhatian konsumen untuk mau melakukan pembelian berulang. Kota Denpasar adalah Ibu Kota Provinsi Bali yang merupakan kota yang cukup padat. Hal ini terbukti dari 9 Cabang Mie Gacoan di Bali 4 diantaranya berada di Kota Denpasar.
Pra-survei telah dilakukan dengan menyebar kuesioner sementara kepada 30 konsumen yang sudah pernah membeli produk Mie Gacoan lebih dari sekali di Kota Denpasar. Berdasarkan hasil pra-survei pada Tabel 1 menunjukkan bahwa dengan adanya social media marketing dapat mempengaruhi pembelian kembali konsumen. Dari sisi brand image membuktikan bahwa repeat purchase pelanggan dari produk Mie Gacoan di Kota Denpasar dipengaruhi dengan adanya brand image yang baik.

Tabel 1.

Hasil Pra-Survei Social Media Marketing di Kota Denpasar

\begin{tabular}{|c|c|c|c|c|c|c|}
\hline \multirow{2}{*}{\multicolumn{2}{|c|}{ Pertanyaan Penyaringan }} & \multirow{2}{*}{ Ya } & \multirow{2}{*}{ Tidak } & \multirow{2}{*}{ Total } & \multicolumn{2}{|c|}{ Presentase } \\
\hline & & & & & Ya & Tidak \\
\hline 1 & $\begin{array}{l}\text { Apakah anda berdomisili di daerah } \\
\text { Denpasar? }\end{array}$ & 30 & 5 & 35 & $85,7 \%$ & $14,3 \%$ \\
\hline \multirow[t]{3}{*}{2} & $\begin{array}{l}\text { Apakah anda pernah membeli produk Mie } \\
\text { gacoan lebih dari sekali dalam } 3 \text { bulan } \\
\text { terakhir? }\end{array}$ & 30 & 5 & 35 & $85,7 \%$ & $14,3 \%$ \\
\hline & \multirow[b]{2}{*}{ Pertanyaan } & \multirow[b]{2}{*}{$\begin{array}{l}\text { Media } \\
\text { Sosial }\end{array}$} & \multirow{2}{*}{$\begin{array}{c}\text { Bertanya } \\
\text { Kepada } \\
\text { Teman }\end{array}$} & \multirow[b]{2}{*}{ Total } & \multicolumn{2}{|c|}{ Presentase } \\
\hline & & & & & $\begin{array}{l}\text { Media } \\
\text { Sosial }\end{array}$ & $\begin{array}{c}\text { Bertanya } \\
\text { Kepada Teman }\end{array}$ \\
\hline 3 & $\begin{array}{l}\text { Dimana biasanya anda mencari informasi } \\
\text { mengenai Mie Gacoan? }\end{array}$ & 23 & 7 & 30 & $76,7 \%$ & $23,3 \%$ \\
\hline & \multirow{2}{*}{ Pertanyaan } & \multirow{2}{*}{ Ya } & \multirow{2}{*}{ Tidak } & \multirow{2}{*}{ Total } & \multicolumn{2}{|c|}{ Presentase } \\
\hline & & & & & Ya & Tidak \\
\hline 4 & $\begin{array}{l}\text { Apakah anda akan berencana untuk membeli } \\
\text { produk dari Mie Gacoan kembali setelah } \\
\text { melihat sosial media Mie Gacoan? }\end{array}$ & 25 & 5 & 30 & $83,3 \%$ & $16,7 \%$ \\
\hline 5 & $\begin{array}{l}\text { Apakah anda akan berencana untuk membeli } \\
\text { kembali produk dari Mie Gacoan karena citra } \\
\text { yang dimiliki oleh Mie Gacoan? }\end{array}$ & 28 & 2 & 30 & $93,3 \%$ & $6,7 \%$ \\
\hline
\end{tabular}

Sumber: Data Diolah, 2021

Penelitian Kristiani \& Dharmayanti (2017) menunjukkan bahwa social media marketing berpengaruh terhadap pembelian berulang. Penelitian serupa yang dilakukan oleh Imron et al. (2018); Kondippli et al., (2016); Kuspriyono \& Nurelasari, (2018); Muchardie et al., (2016); Rohani et al.,
(2020). Namun, Hal yang berbeda terdapat pada hasil penelitian dari Fahmi et al., (2020) yang menunjukkan bahwa social media marketing tidak berpengaruh signifikan terhadap pembelian berulang pada fast-food restoran di Kota Medan. Hal ini dikarenakan pelayanan yang diberikan pada sosial media 
tidak memberikan pengaruh terhadap keputusan pembelian berulang.

Berdasarkan pra survei yang telah dilakukan dan research gap dari penelitian sebelumnya, maka perlu dilakukan penelitian dengan melibatkan brand image sebagai variabel mediasi. Selain social media marketing, persepsi konsumen kepada suatu brand pada industri restoran merupakan hal yang penting untuk menunjang terjadinya repeat purchase. Pembelian berulang dalam industri restoran dapat dijadikan acuan untuk mempertahankan keberadaan dan keberlangsungan industri restoran (Fahmi et al., 2020). Dimana brand image merupakan kepribadian atau citra yang dibentuk didalam benak konsumen melalui informasi dan ekspektasi yang diharapkan melalui suatu produk atau jasa (Sudaryono, 2016). Brand image dapat mempengaruhi repeat purchase pada restoran di Kota Surabaya (Kristiani \& Dharmayanti, 2017). Hal ini membuktikan bahwa dengan adanya citra merek akan dapat meningkatkan terjadinya pembelian berulang dari konsumen dengan cara memberikan informasi produk yang jelas dan terbaru kepada konsumen. Berdasarkan latar belakang tersebut, penelitian ini bertujuan untuk menjelaskan dan menguji peran brand image memediasi pengaruh social media marketing terhadapi repeati purchasei pada pelanggan Mie Gacoan di Kota Denpasar.

Perilaku konsumen menurut Hasan (2013:161) didefinisikan sebagai salah satu ilmu yang mempelajari proses seseorang atau kelompok dalam memilih, membeli, mengkonsumsi produk atau jasa yang bertujuan untuk memuaskan kebutuhan dan keinginan konsumen tersebut. Menurut
Setiadi (2015:2) perilaku konsumen adalah tindakan konsumen yang secara langsung dalam mencari informasi, mendapatkan dan mengatur serta mengonsumsi produk atau jasa, dan juga dalam proses dalam membuat keputusan. Sedangkan (Kotler \& Keller (2016:179) bahwa perilaku konsumen adalah sebuah ilmu yang mempelajari mengenai individu, kelompok, dan organisasi dalam memilih, menggunakan, dan bagaimana barang, jasa, ide atau pegalaman untuk memuaskan kebutuhan dan keinginan mereka. Berdasarkan definisi para ahli tersebut dapat disimpulkan bahwa perilaku konsumen adalah studi yang mempelajari mengenai pola dan tingkah laku konsumen mulai dari memilih, membeli, menggunakan, serta mengatur produk yang bertujuan untuk memuaskan keinginan konsumen. Perilaku konsumen ini menggambarkan bagaimana proses produk mulai dari konsumen memilih sampai menimbulkan keputusan pembelian dan apakah akan memutuskan untuk membeli ulang produk tersebut.

Repeat Purchase merupakan perilaku konsumen dalam pembelian suatu produk lebih dari satu kali (Wijaya \& Suparna, 2017). Keputusan pembelian ulang adalah keputusan untuk menggunakan kembali produk atau jasa sama seperti sebelumnya yang memiliki arti bahwa produk tersebut sudah memenuhi ekspetasi dari konsumen (Suryani \& Rosalina, 2019). Penelitian dari Kristiani \& Dharmayanti (2017) pada industri fast-food restoran di Surabaya menyatakan bahwa repeat purchase dipengaruhi oleh social media marketing dan brand image. Adanya pemasaran yang baik melalui media sosial dengan cara melayani konsumen, 
menjawab pertanyaan, dan mebuat konten yang menarik maka akan dapat meningkatkan terjadinya pembelian ulang, selain itu brand image yang baik dengan cara pemberian informasi yang jelas dan ter-update mengenai produk yang ditawarkan juga dapat meningkatkan terjadinya pembelian berulang pada fast-food restoran di Surabaya. Menurut Wijaya \& Suparna (2017); Pamungkas \& Widodo (2018) dalam mengukur repeat purchase menggunakan tiga indikator, yakni: 1) Konsumen akan datang kembali untuk pembelian produk, 2) Konsumen akan datang lagi untuk mencoba produk baru di waktu yang akan datang, 3) Konsumen akan membeli produk walaupun banyak terdapat produk sejenis yang serupa.

Citra merek atau brand image merupakan persepsi yang berada dibenak konsumen untuk menjadi pembeda diantara merek lainnya misalnya, desain kemasan, huruf, lambing dan warna (Venessa \& Arifin, 2017). Brand image terbentuk dari perkumpulan beberapa brand yang dikembangkan konsumen dalam pikiran mereka (Jokinen, 2016). Adanya brand image yang baik dapat meningkatkan terjadinya repeat purchase dari konsumennya. Hal ini disampaikan oleh Pamungkas \& Widodo (2018) pada penelitiannya yang dilakukan pada Green Product Pertamax Turbo (RON98) di Kota Bandung. Pelanggan yang mengakui brand image merupakan gambaran dari keseluruhan persepsi terhadap merek yang dibentuk dari informasi dan pengalaman masa lalu terhadap merek tersebut, maka persepsi dan kepercayaan yang dipegang oleh konsumen terhadap merek tentu saja akan melekat dalam benak konsumen, oleh karena itu konsumen akan melakukan pembelian berulang serta tidak mudah untuk dipengaruhi oleh merek yang lain. Ada tiga indikator yang digunakan untuk membentuk brand image yang disampaikan oleh Venessa \& Arifin (2017); Pamungkas \& Widodo (2018) yakni: 1) Citra perusahaan, 2) Citra pemakai, 3) Citra dari produk itu sendiri.

Social media marketing adalah kegiatan yang bertujuan untuk menghasilkan suatu konten yang dibagikan oleh konsumen kepada pengguna yang lain sehingga dapat meningkatkan nilai merek dan memperluas jangkauan pelanggan (Mileva \& Fauzi, 2018). Social media marketing merupakan proses yang memanfaatkan promosi situs web, layanan, dan produk melalui online yang melibatkan kegiatan yang terkait pemasaran seperti blogging, berbagi foto (Yazdanparast et al., 2016) dan terdiri dari alat, platform, dan aplikasi yang memungkinkan pelanggan terhubung dan berkomunikasi satu sama lain (Pinto \& Yagnik, 2016). Menurut Mileva \& Fauzi (2018); Maulani \& Sanawiri (2019) terdapat empat indikator yang dijadikan alat untuk mengukur social media marketing: 1) Content creation, yaitu membuat konten yang menarik menjadi dasar acuan dalam melakukan social media marketing, 2) Content sharing yaitu sosial media dapat sharing konten kepada komunitas atau kelompok sosial yang dapat membantu memperluas jaringan dari bisnis dan memperluas jangkauan target pasar, 3) Connection, yaitu dengan menggunakan sosial media, memungkinan untuk berkenalan dengan lebih banyak orang yang memiliki ketertarikan yang sama, 4) Community building, yaitu sebuah komunitas online yang 
Peran Brand Image Memediasi Pengaruh...

Ni Luh Widya Uttari \& I Gusti Ayu Ketut Giantari

dimana terjadi komunikasi dan interaksi antar orang yang ada diseluruh dunia dengan memanfaatkan teknologi.

Berdasarkan hasil penelitian terdahulu maka hipotesis pada penelitian ini dapat dijelaskan sebagai berikut:

$\mathrm{H}^{1}$ : Social media marketing berpengaruh positif dan signifikan terhadap repeat purchase

$\mathrm{H}^{2}$ : Social media marketing berpengaruh positif signifikan terhadap brand image

$\mathrm{H}^{3}$ : Brand image berpengaruh positif signifikan terhadap repeat purchase
$\mathrm{H}^{4}$ : Brand image berpengaruh signifikan dalam memediasi pengaruhi social media marketing terhadap repeat purchase

\section{METODE PENELITIAN}

Jenis penelitian ini digolongkan kedalam penelitian asosiatif yang menjelaskan hubungan antar variabel social media marketing, brand image, dan repeat purchase, khususnya pada pelanggan Mie Gacoan di Kota Denpasar.

Tabel 2.

Indikator Variabel Penelitian

\begin{tabular}{|c|c|c|}
\hline Variabel & Indikator & Sumber \\
\hline $\begin{array}{c}\text { Repeat Purchase } \\
\left(\mathrm{Y}_{1}\right)\end{array}$ & $\begin{array}{l}\text { 1) Konsumen akan datang kembali untuk pembelian produk. }\left(\mathrm{Y}_{1.1}\right) \\
\text { 2) Konsumen akan datang lagi untuk mencoba produk baru di } \\
\left.\text { waktu yang akan datang. ( } \mathrm{Y}_{1.2}\right) \\
\text { 3) Konsumen akan membeli produk walaupun banyak terdapat } \\
\text { produk sejenis yang serupa. }\left(\mathrm{Y}_{1.3}\right)\end{array}$ & $\begin{array}{l}\text { Pamungkas \& } \\
\text { Widodo (2018) } \\
\text { Wijaya \& Suparna } \\
\text { (2017) }\end{array}$ \\
\hline $\begin{array}{l}\text { Brand Image } \\
\qquad\left(\mathrm{Y}_{2}\right)\end{array}$ & $\begin{array}{l}\text { 1) Citra perusahaan. }\left(\mathrm{Y}_{2.1} \& \mathrm{Y}_{2.2}\right) \\
\text { 2) Citra pemakai }\left(\mathrm{Y}_{2.3} \& \mathrm{Y}_{2.4}\right) \\
\text { 3) Citra dari produk itu sendiri }\left(\mathrm{Y}_{2.5} \& \mathrm{Y}_{2.6}\right)\end{array}$ & $\begin{array}{l}\text { Pamungkas \& } \\
\text { Widodo (2018); } \\
\text { Venessa \& Arifin } \\
(2017)\end{array}$ \\
\hline $\begin{array}{l}\text { Social Media } \\
\text { Marketing } \\
\quad(\mathrm{X})\end{array}$ & $\begin{array}{l}\text { 1) Content Creation }\left(\mathrm{X}_{1}\right) \\
\text { 2) Content Sharing }\left(\mathrm{X}_{2}\right) \\
\text { 3) Connection }\left(\mathrm{X}_{3}\right) \\
\text { 4) Community Building }\left(\mathrm{X}_{4}\right)\end{array}$ & $\begin{array}{l}\text { Mileva \& Fauzi } \\
\text { (2018); Maulani \& } \\
\text { Sanawiri (2019) }\end{array}$ \\
\hline
\end{tabular}

Sumber : Data diolah, 2021

Lokasi penelitian ini dilakukan di Kota Denpasar dikarenakan hasil survei dari Sosial Ekonomi Nasional (Susenas) BPS 2018 Tingkat penggunaan internet dan media sosial di Kota Denpasar dapat dikatakan cukup tinggi sebesar 60,58 persen. Selain itu, 4 dari 9 Cabang Mie Gacoan terletak di Kota Denpasar. Tingginya intensitas jumlah pengguna media internet di Kota Denpasar, serta sebagian besar cabang Mie Gacoan berada di Kota Denpasar. Maka dari itu, Kota Denpasar dinilai sesuai untuk dijadikan lokasi penelitian. Objek dari penelitian ini adalah social media marketing, brand image dan repeat purchase sedangkan subjek penelitian adalah pelanggan yang sudah melakukan pembelian Mie Gacoan lebih dari 2 kali yang bertempat di Kota Denpasar. Variabel endogen dalam penelitian ini adalah repeat purchase $\left(\mathrm{Y}_{1}\right)$. Variabel mediasi dalam 
penelitian ini adalah brand image $\left(\mathrm{Y}_{2}\right)$. Variabel Eksogen dalam penelitian ini adalah social media marketing (X). Populasi dalam penelitian ini adalah pelanggan Mie Gacoan yang berdomisili di Kota Denpasar. Penelitian ini menggunakan sampel sebanyak 130 responden.

Sampel diambil menggunakan teknik non probability sampling yakni purposive sampling yaitu teknik penentuan sampel dengan pertimbangan tertentu Sugiyono (2018: 156). Kriteria penentuan sampel dalam penelitian ini yaitu: 1) Responden berdomisili di Kota Denpasar. 2) Minimal berpendidikan SMA/SMK sederajat. Alasan pertimbangan ini digunakan adalah seseorang dengan jenjang Pendidikan SMA/SMK dapat memahami dan mengerti dalam pengisian kuesioner. 3) Sering menggunakan media sosial. 4) Sudah pernah membeli produk mie gacoan lebih dari sekali.

Terdapat dua jenis data yang digunakan dalam penelitian ini, yakni data kuantitatif dan data kualitatif. Data kualitatif dalam penelitian ini berupa pendapat dari responden dalam menjawab pertanyaanpertanyaan yang tertera dalam kuesioner mengenai variabel penelitian, yaitu social media marketing, brand image, dan repeat purchase pada pelanggan Mie Gacoan di Kota Denpasar. Data kuantitatif dalam penelitian ini merupakan data dari hasil tabulasi tanggapan responden dari daftar penyataan dalam kuesioner.

Sumber data dalam penelitan adalah sumber data primer dan sumber data sekunder. Sumber primer dalam penelitian ini, berupa pendapat responden dalam responden mengenai variabel-variabel dalam penelitian. Sumber data sekunder dalam penelitin ini diperoleh dari referensi pada buku, jurnal dan situs internet yang dapat memberikan informasi yang sesuai dengan masalah penelitian.

Metode pengumpulan data dalam penelitian ini yaitu berupa kuesioner yang di sebarkan secara langsung berupa google form kepada responden. Skala pengukuran yang digunakan dalam penelitian ini adalah skala likert dengan skala 1 (satu) sampai 5 (lima). Skala ini digunakan untuk mengukur sikap, pendapat, dan persepsi seseorang atau sekelompok orang tentang fenomena sosial (Sugiyono, 2018: 168). Skala likert yang digunakan yaitu skor 1 untuk sangat tidak setuju (STS) sampai dengan 5 untuk sangat setuju (SS).

Uji validitas bertujuan untuk mengetahui ketepatan tiap butir atau item instrumen. Sebagai uji coba instrumen, maka data yang digunakan dalam uji validitas sebanyak 30 responden yang merupakan sampel dalam populasi penelitian. Apabila koefisien korelasi $\geq 0,30$ maka instrumen tersebut dapat dikatakan valid (Sugiyono, 2018: 208). Uji reliabilitas bertujuan untuk menetapkan apakah instrumen kuisioner dapat digunakan lebih dari satu kali, dengan responden yang sama atau berbeda dalam waktu yang berbeda (Sugiyono, 2018: 209). Untuk mengukur reliabilitas instrumen dalam penelitian ini adalah dengan menggunakan teknik Cronbach alpha dengan program SPSS for windows. Data yang digunakan dalam uji reliabilitas sebanyak 30 responden yang merupakan sampel dalam populasi penelitian. Suatu variabel dikatakan reliabel jika nilai Cronbach Alpha $>0,60$. 
Peran Brand Image Memediasi Pengaruh... Ni Luh Widya Uttari \& I Gusti Ayu Ketut Giantari

Teknik analisis yang digunakan dalam penelitian ini yaitu teknik analisis Structural Equation Modeling berbasis Partial Least Square (SEM-PLS). SEM dan PLS ini dapat menjelaskan kompleksitas hubungan antara variabel pada praktiknya variabel-variabel tersebut pada bidang tertentu tidak dapat diukur secara langsung (bersifat laten atau tersembunyi) sehingga membutuhkan indikator-indikator (manifes) untuk mengukurnya. Ghozali (2014: 37) menyatakan langkah-langkah analisis PLS dapat dilakukan dengan merancang Outer Model (Model Pengukuran) yang bertujuan untuk mengetahui apakah indikator bersifat reflektif atau formatif, dan merancang Inner Model (Model Struktural) yang dirancang berdasarkan rumusan masalah atau hipotesis.

\section{HASIL DAN PEMBAHASAN}

Responden dalam penelitian ini adalah 130 responden yang merupakan pelanggan Mie Gacoan yang berdomisili di Kota Denpasar. Tabel 3 menunjukkan hasil klasifikasi responden dalam penelitian ini didominasi oleh perempuan, berusia 21-30 tahun. Latar belakanag Pendidikan mulai dari SMA sampai dengan pascasarjana. Sebagian besar responden memiliki pekerjaan sebagai mahasiswa/pelajar dengan penghasilan ratarata perbulannya kurang dari satu juta rupiah. Seluruh responden dalam penelitian ini pernah membeli produk Mie Gacoan lebih dari sekali dalam kurun waku 3 bulan terakhir.

Tabel 3.

Karakteristik Responden

\begin{tabular}{|c|c|c|c|c|}
\hline No & Karakteristik & Klasifikasi & $\begin{array}{c}\text { Jumlah Responden } \\
\text { (Orang) }\end{array}$ & Presentase $(\%)$ \\
\hline \multirow{2}{*}{1} & \multirow{2}{*}{ Jenis Kelamin } & Laki-laki & 42 & 32 \\
\hline & & Perempuan & 88 & 68 \\
\hline \multirow{3}{*}{2} & & Total & 130 & 100 \\
\hline & \multirow[b]{2}{*}{ Usia } & $\leq 20$ tahun & 32 & 25 \\
\hline & & $21-30$ tahun & 98 & 75 \\
\hline & & Total & 130 & 100 \\
\hline \multirow{3}{*}{3} & \multirow{3}{*}{$\begin{array}{l}\text { Pendidikan yang } \\
\text { diselesaikan }\end{array}$} & SMA/sederajat & 110 & 85 \\
\hline & & Diploma/sederajat & 8 & 6 \\
\hline & & S1 & 12 & 9 \\
\hline & & Total & 130 & 100 \\
\hline \multirow{4}{*}{4} & \multirow{3}{*}{ Pekerjaan } & Mahasiswa/Pelajar & 100 & 77 \\
\hline & & Karyawan Swasta & 29 & 22 \\
\hline & & Wiraswasta & 1 & 1 \\
\hline & & Total & 130 & 100 \\
\hline \multirow{5}{*}{5} & \multirow{4}{*}{ Penghasilan perbulannya } & < Rp. 1.000 .000 & 78 & 60 \\
\hline & & Rp 1.000.000 - Rp. 2.499 .000 & 31 & 24 \\
\hline & & $\operatorname{Rp} 2.500 .000-\operatorname{Rp} 4.999 .000$ & 20 & 15 \\
\hline & & $>\operatorname{Rp} 5.000 .000$ & 1 & 1 \\
\hline & \multirow{5}{*}{$\begin{array}{l}\text { Rata-rata menggunakan } \\
\text { sosial media }\end{array}$} & Total & 130 & 100 \\
\hline \multirow{4}{*}{6} & & $<1$ jam & 6 & 5 \\
\hline & & 1-3 jam & 36 & 28 \\
\hline & & $>3 \mathrm{jam}$ & 88 & 68 \\
\hline & & Total & 130 & 100 \\
\hline
\end{tabular}

Sumber: Data diolah, 2021 
Peran Brand Image Memediasi Pengaruh...

Ni Luh Widya Uttari \& I Gusti Ayu Ketut Giantari

Tabel 4.

Tanggapan Responden Atas Variabel Repeat Purchase

\begin{tabular}{|c|c|c|c|c|c|c|c|c|c|}
\hline \multirow[t]{2}{*}{ No } & \multirow{2}{*}{ Pernyataan } & \multicolumn{5}{|c|}{$\begin{array}{c}\text { Frekuensi Jawaban } \\
\text { Responden }\end{array}$} & \multirow{2}{*}{ Jumlah } & \multirow{2}{*}{$\begin{array}{c}\text { Rata- } \\
\text { rata }\end{array}$} & \multirow[t]{2}{*}{ Ket } \\
\hline & & SS & TS & $\mathbf{N}$ & $\mathbf{S}$ & SS & & & \\
\hline 1 & $\begin{array}{l}\text { Konsumen Mie Gacoan akan kembali untuk } \\
\text { membeli produk Mie Gacoan lagi. }\end{array}$ & 0 & 5 & 17 & 56 & 52 & 545 & 4,19 & Tinggi \\
\hline 2 & $\begin{array}{l}\text { Konsumen akan kembali untuk mencoba } \\
\text { produk baru dari Mie Gacoan pada masa } \\
\text { mendatang. }\end{array}$ & 1 & 6 & 19 & 63 & 41 & 527 & 4,05 & Tinggi \\
\hline 3 & $\begin{array}{l}\text { Konsumen akan mengkonsumsi Mie Gacoan } \\
\text { walaupun banyak terdapat restoran atau café } \\
\text { yang memiliki produk sejenis }\end{array}$ & 2 & 10 & 34 & 49 & 35 & 495 & 3,81 & Tinggi \\
\hline \multicolumn{8}{|c|}{ Rata-rata keseluruhan Repeat Purchase } & 4,02 & Tinggi \\
\hline
\end{tabular}

Sumber: Data diolah, 2021

Repeat purchase pada penelitian ini merupakan variabel endogen yang diukur dengan 3 pernyataan. Secara rinci hasil penelitian mengenai persepsi responden terhadap repeat purchase pada Tabel 4 yang menunjukan skor rata-rata variabel repeat purchase sebesar 4,02 yang menunjukkan bahwa pelanggan Mie Gacoan di Kota Denpasar memiliki keputusan untuk membeli ulang yang tinggi. Secara rinci hasil penelitian mengenai persepsi responden terhadap repeat purchase pada Tabel 4 yang menunjukan skor rata-rata variabel repeat purchase sebesar 4,02 yang menunjukkan bahwa pelanggan Mie Gacoan di Kota Denpasar memiliki keputusan untuk membeli ulang yang tinggi. Dilihat dari persepsi responden mengenai repeat purchase, maka ini artinya Mie Gacoan di Kota Depasar dapat menarik konsumennya untuk melakukan repeat purchase melalui produk baru yang disediakan dan produk unggulannya.

Tabel 5.

Tanggapan Responden atas Variabel Brand Image

\begin{tabular}{|c|c|c|c|c|c|c|c|c|c|}
\hline \multirow[t]{2}{*}{ No } & \multirow[t]{2}{*}{ Pernyataan } & \multicolumn{5}{|c|}{$\begin{array}{c}\text { Frekuensi Jawaban } \\
\text { Responden }\end{array}$} & \multirow[t]{2}{*}{ Jumlah } & \multirow{2}{*}{$\begin{array}{l}\text { Rata- } \\
\text { rata }\end{array}$} & \multirow[t]{2}{*}{ Ket } \\
\hline & & SS & TS & $\mathbf{N}$ & $\mathbf{S}$ & SS & & & \\
\hline 1 & $\begin{array}{l}\text { Logo Mie Gacoan dapat dengan mudah } \\
\text { diketahui oleh konsumen. }\end{array}$ & 0 & 1 & 12 & 51 & 66 & 572 & 4,40 & $\begin{array}{l}\text { Sangat } \\
\text { Baik }\end{array}$ \\
\hline 2 & $\begin{array}{l}\text { Cabang penjualan Mie Gacoan di Kota } \\
\text { Denpasar mudah ditemukan. }\end{array}$ & 0 & 0 & 9 & 41 & 80 & 591 & 4,55 & $\begin{array}{l}\text { Sangat } \\
\text { Baik }\end{array}$ \\
\hline 3 & $\begin{array}{l}\text { Harapan konsumen terhadap produk Mie } \\
\text { Gacoan selalu terpenuhi. }\end{array}$ & 0 & 4 & 30 & 65 & 31 & 513 & 3,95 & Baik \\
\hline 4 & $\begin{array}{l}\text { Mengkonsumsi produk Mie Gacoan membuat } \\
\text { anda merasa percaya diri. }\end{array}$ & 3 & 13 & 57 & 43 & 14 & 442 & 3,40 & Baik \\
\hline 5 & Produk Mie Gacoan terjamin kualitasnya. & 0 & 2 & 34 & 67 & 27 & 509 & 3,92 & Baik \\
\hline 6 & Desain produk dari Mie Gacoan menarik. & 0 & 1 & 35 & 58 & 36 & 519 & 3,99 & Baik \\
\hline
\end{tabular}

Sumber: Data diolah, 2021

Rata-rata keseluruhan Brand Image 
Brand image dalam penelitian ini yaitu sebagai variabel mediasi. Brand image pada penelitian ini diukur dengan 6 indikator. Secara rinci hasil penelitian mengenai persepsi responden terhadap brand image pada Tabel 5 yang menunjukkan rata-rata skor presentase brand image secara keseluruhan adalah sebesar 4.03 yang berarti bahwa tanggapan reponden mengenai brand image Mie Gacoan tergolong tinggi. Dari persepsi responden mengenai brand image Mie Gacoan di Kota Denpasar, maka dapat disimpulkan bahwa Mie Gacoan memiliki brand image yang baik dibenak konsumennya.

Tabel 6.

Tanggapan Responden Atas Variabel Social Media Marketing

\begin{tabular}{|c|c|c|c|c|c|c|c|c|c|}
\hline \multirow[t]{2}{*}{ No } & \multirow[t]{2}{*}{ Pernyataan } & \multicolumn{5}{|c|}{$\begin{array}{c}\text { Frekuensi Jawaban } \\
\text { Responden }\end{array}$} & \multirow[t]{2}{*}{ Jumlah } & \multirow{2}{*}{$\begin{array}{c}\text { Rata- } \\
\text { rata }\end{array}$} & \multirow[t]{2}{*}{ Ket } \\
\hline & & SS & TS & $\mathbf{N}$ & $\mathbf{S}$ & SS & & & \\
\hline 1 & $\begin{array}{l}\text { Mie Gacoan membuat konsep sosial } \\
\text { media yang menarik }\end{array}$ & 1 & 5 & 39 & 61 & 24 & 492 & 3,78 & Baik \\
\hline 2 & $\begin{array}{l}\text { Mie Gacoan membuat konten (foto, } \\
\text { video) berisikan informasi yang lengkap } \\
\text { untuk konsumen }\end{array}$ & 0 & 6 & 36 & 60 & 28 & 500 & 3,85 & Baik \\
\hline 3 & $\begin{array}{l}\text { Mie Gacoan menggunakan sosial media } \\
\text { sebagai penghubung dengan konsumen. }\end{array}$ & 0 & 3 & 26 & 65 & 36 & 524 & 4,03 & Baik \\
\hline 4 & $\begin{array}{l}\text { Sosial media Mie Gacoan sebagai } \\
\text { tempat untuk membangun komunitas } \\
\text { dan bertukar informasi. }\end{array}$ & 0 & 9 & 30 & 62 & 29 & 501 & 3,85 & Baik \\
\hline \multicolumn{8}{|c|}{ Rata-rata keseluruhan Social Media Marketing } & 3,88 & Baik \\
\hline
\end{tabular}

Sumber: Data diolah, 2021

Social media marketing pada penelitian ini merupakan variabel eksogen yang diukur dengan 4 indikator. Secara rinci hasil penelitian mengenai persepsi responden terhadap social media marketing pada Tabel 6 yang menunjukkan rata-rata skor presentase social media marketing secara keseluruhan adalah sebesar 3,88 yang berarti tanggapan reponden mengenai Mie Gacoan dalam memanfaatkan social media marketing tergolong baik. Dari persepsi responden mengenai social media marketing artinya Mie Gacoan dapat memanfaatkan penggunaan social media marketing dengan baik.

Outer model merupakan evaluasi pengukuran yang dilakukan untuk mengukur validitas dan realibilitas dari model penelitian ini. Kriteria validitas indikator diukur dengan convergent validity, sedangkan reabilitas diukur dengan composite reliability dan average variance extracted (AVE). Gambar 1 merupakan gambar evaluasi outer model.

Convergent Validity dilakukan dengan melihat nilai koefisien outer loading dari tiap indikator pada variabel reflektif. Pada Tabel 7 merupakan hasil pengukuran convergent validity yang menunjukkan bahwa seluruh nilai outer loading indikator variabel memiliki nilai lebih besar dari 0,60 maka dapat disimpulkan bahwa seluruh indikator telah memenuhi persyaratan convergent validity dan dinyatakan valid. 


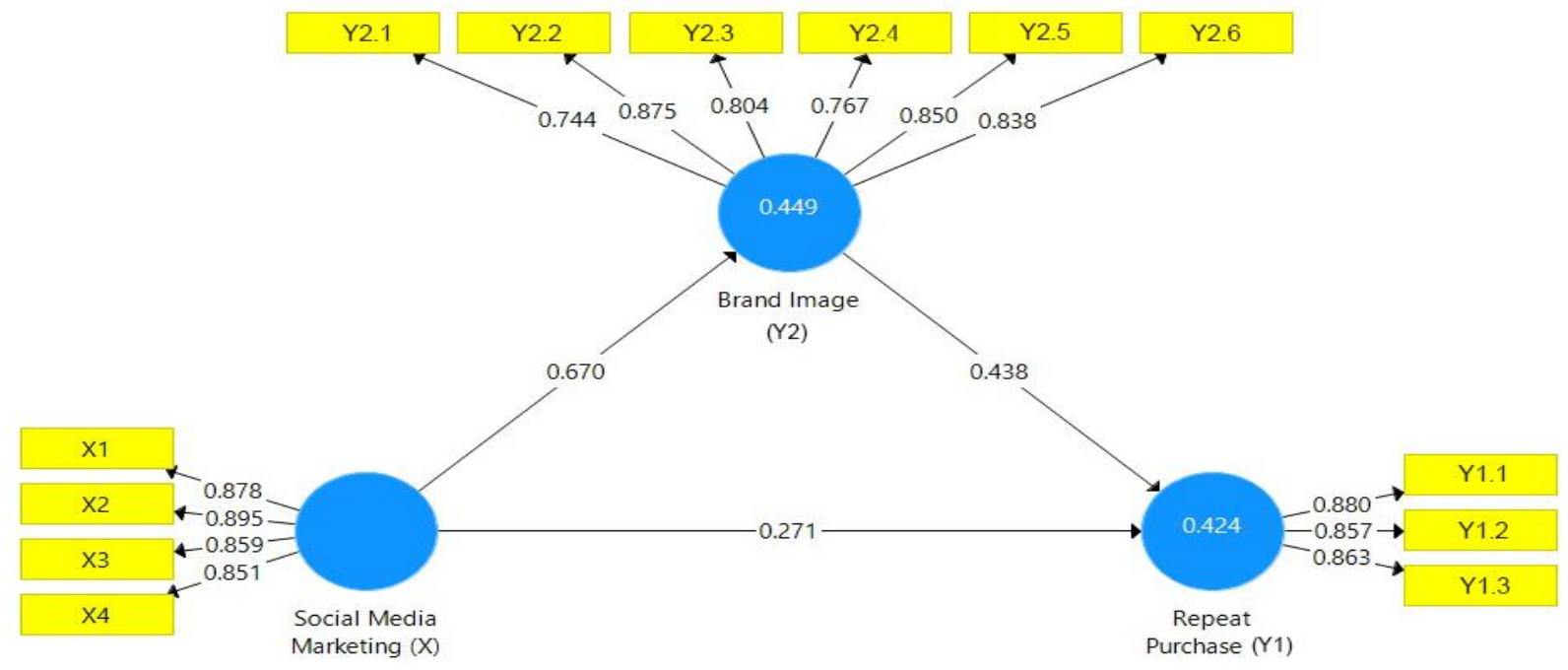

Sumber: Data diolah, 2021

Gambar 1.

Diagram Jalur Evaluasi Outer Model

Tabel 7.

Hasil Uji Convergent Validity

\begin{tabular}{|c|c|c|c|}
\hline Variabel & Indikator & Outer Loading & Keterangan \\
\hline \multirow{3}{*}{$\begin{array}{l}\text { Repeat Purchase } \\
\left(\mathrm{Y}_{1}\right)\end{array}$} & $\mathrm{Y}_{1.1}$ & 0,880 & Valid \\
\hline & $\mathrm{Y}_{1.2}$ & 0,857 & Valid \\
\hline & $Y_{1.3}$ & 0,863 & Valid \\
\hline \multirow{6}{*}{$\begin{array}{l}\text { Brand Image } \\
\qquad\left(\mathrm{Y}_{2}\right)\end{array}$} & $\mathrm{Y}_{2.1}$ & 0,744 & Valid \\
\hline & $\mathrm{Y}_{2.2}$ & 0,875 & Valid \\
\hline & $\mathrm{Y}_{2.3}$ & 0,804 & Valid \\
\hline & $\mathrm{Y}_{2.4}$ & 0,767 & Valid \\
\hline & $\mathrm{Y}_{2.5}$ & 0,850 & Valid \\
\hline & $\mathrm{Y}_{2.6}$ & 0,838 & Valid \\
\hline \multirow{4}{*}{$\begin{array}{l}\text { Social Media Marketing } \\
\text { (X) }\end{array}$} & $\mathrm{X}_{1}$ & 0,878 & Valid \\
\hline & $\mathrm{X}_{2}$ & 0,895 & Valid \\
\hline & $\mathrm{X}_{3}$ & 0,859 & Valid \\
\hline & $\mathrm{X}_{4}$ & 0,851 & Valid \\
\hline
\end{tabular}

Sumber: Data diolah, 2021

Discriminant Validity adalah pembanding yang baik untuk model apabila pengukuran indikator reflektif yang diukur nilai validitas diskriminan lebih besar besar berdasarkan cross loading dengan variabel latennya. Indikator dapat dikatakan valid dari 0,60. Tabel 8 menjelaskan bahwa adanya apabila nilai cross loading setiap indikator dari variabel yang bersangkutan lebih besar dibandingkan dengan cross loading variabel lainnya. Variabel laten dinyatakan menjadi discriminant validity yang sangat baik. Hal ini dapat dilihat dari nilai cross loading setiap indikator dari variabel yang bersangktan lebih besar dari 0,60, maka dapat disimpilkan data dalam penelitian ini dinyatakan valid. 
Metode lainnya yang digunakan untuk menilai discriminant validity yaitu dengan melihat nilai average variance extracted (AVE), Suatu model perhitungan dapat dikatakan baik apabila nilai AVE masingmasing konstruk memiliki nilai lebih besar dari 0,50. Tabel 9 merupakan hasil output AVE yang menunjukkan bahwa nilai AVE baik variabel repeat purchase, social media marketing dan brand image memiliki nilai AVE lebih besar dari 0,50
Uji reliabilitas konstruk dapat dilakukan dengan composite reliability dan cronbach's alpha. Variabel dinyatakan reliabel jika nilai composite reliability di atas 0,70. Tabel 10 merupakan hasil output dari composite reliability dan Cronbach's alpha baik itu dari variabel repeat purchase, social media marketing, dan brand image memiliki nilai diatas 0,70. Jadi, dapat disimpulkan bahwa seluruh variabel pada penelitian ini memiliki reliabilitas yang baik

Tabel 8.

Hasil Uji Dicriminant Validity

\begin{tabular}{cccc}
\hline & Brand Image $\left(\mathrm{Y}_{2}\right)$ & Repeat Purchase $\left(\mathrm{Y}_{1}\right)$ & Social Media Marketing $(\mathrm{X})$ \\
\hline $\mathrm{Y}_{2.1}$ & $\mathbf{0 , 7 4 4}$ & 0,411 & 0,478 \\
$\mathrm{Y}_{2.2}$ & $\mathbf{0 , 8 7 5}$ & 0,336 & 0,290 \\
$\mathrm{Y}_{2.3}$ & $\mathbf{0 , 8 0 4}$ & 0,430 & 0,525 \\
$\mathrm{Y}_{2.4}$ & $\mathbf{0 , 7 6 7}$ & 0,502 & 0,551 \\
$\mathrm{Y}_{2.5}$ & $\mathbf{0 , 8 5 0}$ & 0,598 & 0,554 \\
$\mathrm{Y}_{2.6}$ & $\mathbf{0 , 8 3 8}$ & 0,481 & 0,574 \\
$\mathrm{X}_{1}$ & 0,608 & 0,518 & $\mathbf{0 , 8 7 8}$ \\
$\mathrm{X}_{2}$ & 0,597 & 0,519 & $\mathbf{0 , 8 9 5}$ \\
$\mathrm{X}_{3}$ & 0,523 & 0,453 & $\mathbf{0 , 8 5 9}$ \\
$\mathrm{X}_{4}$ & 0,600 & 0,471 & $\mathbf{0 , 8 5 1}$ \\
$\mathrm{Y}_{1.1}$ & 0,529 & $\mathbf{0 , 8 8 0}$ & 0,444 \\
$\mathrm{Y}_{1.2}$ & 0,482 & $\mathbf{0 , 8 5 7}$ & 0,503 \\
$\mathrm{Y}_{1.3}$ & 0,591 & $\mathbf{0 , 8 6 3}$ & 0,517
\end{tabular}

Sumber: Data diolah, 2021

Tabel 9.

Hasil Average Variance Extracted

\begin{tabular}{lc}
\hline \multicolumn{1}{c}{ Variabel } & Average Variance Extrated (AVE) \\
\hline Repeat Purchase $\left(\mathrm{Y}_{1}\right)$ & 0,751 \\
Brand Image $\left(\mathrm{Y}_{2}\right)$ & 0,569 \\
Social Media Marketing $(\mathrm{X})$ & 0,758 \\
\hline
\end{tabular}

Sumber: Data diolah, 2021

Tabel 10.

Hasil Composite Reliability

\begin{tabular}{lcc}
\hline \multicolumn{1}{c}{ Variabel } & Composite Reliability & Cronbach's Alpha \\
\hline Repeat Purchase $\left(\mathrm{Y}_{1}\right)$ & 0,900 & 0,844 \\
Brand Image $\left(\mathrm{Y}_{2}\right)$ & 0,886 & 0,894 \\
Social Media Marketing $(\mathrm{X})$ & 0,926 & 0,835 \\
\hline
\end{tabular}

Sumber: Data diolah, 2021 
Pengujian inner model dilakukan dengan melihat nilai $R$-square atau goodness of fit model. R-square model PLS dapat dievaluasi dengan melihat R-square predictive relevance untuk model variabel. Selain itu, dalam menilai model struktural dengan struktural PLS dapat dilihat juga dari nilai $Q$-square untuk setiap variabel laten endogen sebagai kekuatan prediksi dan model struktural. Jika hasil perhitungan memperlihatkan nilai $Q$-square lebih dari nol, maka model dinyatakan layak dan memiliki nilai prediktif yang relevan. Diagram jalur dari evaluasi inner model dapat dilihat pada Gambar 2.

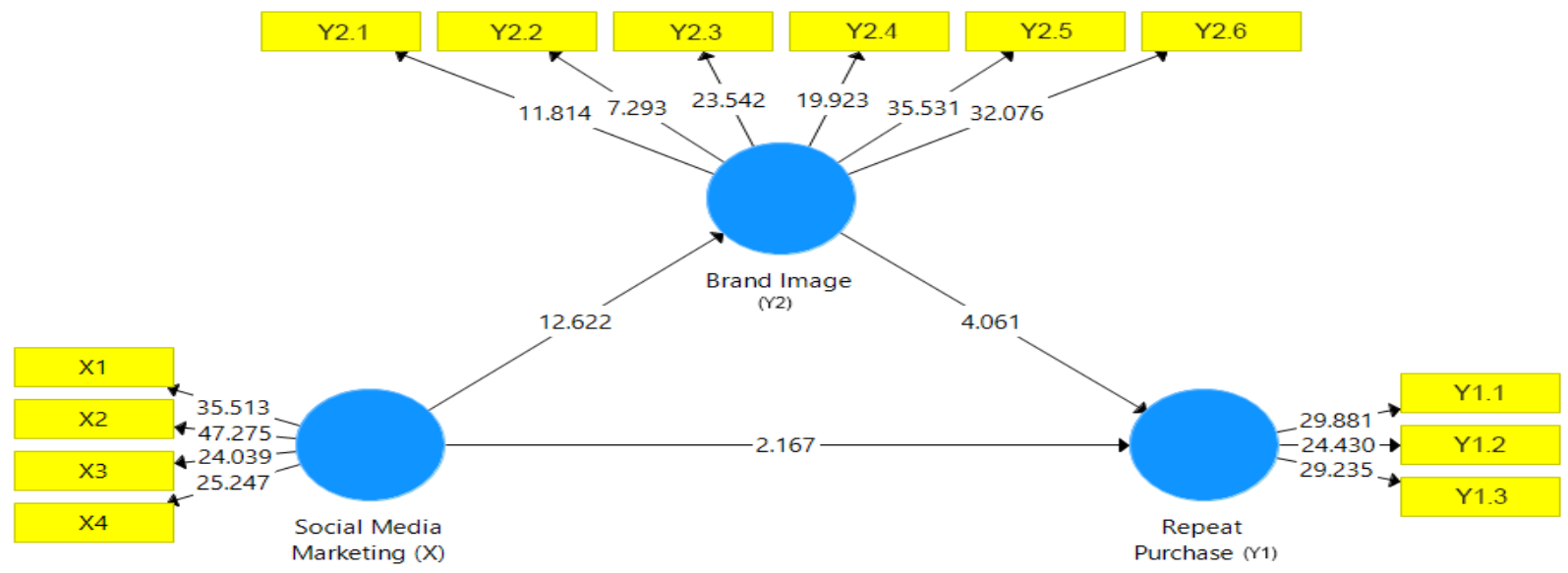

Sumber: Data diolah, 2021

Gambar 2.

Diagram Jalur Evaluasi Inner Model

$R$-square atau uji goodness of fit mengukur seberapa besar pengaruh variabel eksogen terhadap variabel endogen. Rentang nilai $R$-square adalah $0-1$, jika nilai $R$-square mendekati mendekati satu, maka semakin kuat pengaruh variabel eksogen terhadap variabel endogen. Sebaliknya jika nilai $R$ square mendekati nol maka semakin lemah pengaruh variabel eksogen terhadap variabel endogen.

Pada Tabel 11 dapat dilihat nilai $R$ square untuk variabel brand image adalah 0,449 persen, yang dapat diinterpretasikan sebanyak 44,9 persen konstruk brand image dipengaruhi oleh social media marketing.
Sedangkan 55,1 persen lainnya dipengaruhi oleh konstruk diluar model. Selanjutnya nilai $R$-square variabel varibel repeat purchase adalah sebesar 0,424, yang dapat diinterpretasikan sebanyak 42,4 persen konstruk repeat purchase dipengaruhi oleh social media marketing dan brand image. Sedangkan 57,6 persen lainnya dipengaruhi oleh konstruk diluar model.

Tabel 11. Nilai $R$-Square

\begin{tabular}{lc}
\hline \multicolumn{1}{c}{ Variabel } & R-square \\
\hline Social Media Marketing $(\mathrm{X})$ & \\
Repeat Purchase $\left(\mathrm{Y}_{1}\right)$ & 0,424 \\
Brand Image $\left(\mathrm{Y}_{2}\right)$ & 0,449 \\
\hline Sumber: Data diolah, 2021 & \\
\hline
\end{tabular}


Pengujian inner model dapat dilakukan juga dengan menghitung nilai $Q$ square. Apabila nilai $Q$-square lebih besar dari nol (0) maka, model mempunyai nilai predictive relevance, sedangkan nilai Qsquare kurang dari nol, maka memperlihatkan bahwa model kurang memiliki predictive relevance. Namun jika hasil perhitungan memperlihatkan nilai $Q$-square lebih dari nol, maka model layak dikatakan memiliki nilai prediktif yang relevan. Perhitungan nilai $Q$ square dapat dilihat sebagai berikut :

$$
\begin{aligned}
& \mathrm{Q}^{2}=1-\left[\left(1-\mathrm{R}^{2}\right)\left(1-\mathrm{R}^{2}\right)\right] \ldots \ldots \ldots \\
& \mathrm{Q}^{2}=1-[(1-0,449)(1-0,424)] \\
& \mathrm{Q}^{2}=1-(0,551)(0,576) \\
& \mathrm{Q}^{2}=1-0,317
\end{aligned}
$$

$$
\mathrm{Q}^{2}=0,683
$$

Nilai $\mathrm{Q}^{2}$ berada pada rentan $0<\mathrm{Q} 2<$ 1 , dimana semakin mendekati 1 berarti model semakin baik. berdasarkan hasil perhitungan diatas menunjukkan nilai predictive relevance sebesar 0,683. Nilai ini lebih besar dari 0 , sehingga dapat diartikan bahwa 68,3 persen variasi pada variabel repeat purchase dijelaskan oleh variabel yang digunakan pada model. 32,1 persen sisanya dijelaskan oleh faktor lainnya di luar model. Dengan hasil ini

\begin{tabular}{|c|c|c|c|c|c|}
\hline Variabel & $\begin{array}{c}\text { Original } \\
\text { Sample }\end{array}$ & $\begin{array}{c}\text { Sample } \\
\text { Mean }\end{array}$ & $\begin{array}{l}\text { Standard } \\
\text { Deviation } \\
\end{array}$ & $\begin{array}{l}\text { T- Statistic } \\
(\mid \text { O/STDEV } \mid)\end{array}$ & $\begin{array}{c}P \\
\text { Values } \\
\end{array}$ \\
\hline $\begin{array}{l}\text { Social Media Marketing }(\mathrm{X}) \rightarrow \text { Repeat Purchase } \\
\left(\mathrm{Y}_{1}\right)\end{array}$ & 0,271 & 0,261 & 0,125 & 2,167 & 0,031 \\
\hline $\begin{array}{l}\text { Social Media Marketing }(\mathrm{X}) \rightarrow \text { Brand Image } \\
\left(\mathrm{Y}_{2}\right)\end{array}$ & 0,670 & 0,673 & 0,053 & 12,622 & 0,000 \\
\hline Brand Image $\left(\mathrm{Y}_{2}\right) \rightarrow$ Repeat Purchase $\left(\mathrm{Y}_{1}\right)$ & 0,438 & 0,446 & 0,108 & 4,061 & 0,000 \\
\hline
\end{tabular}
maka disimpulkan model ini memiliki nilai prediktif relevan.

Tabel 12.

Path Coefficients (Koefisien Jalur)

Sumber: Data diolah, 2021

Pengujian hipotesis menggunakan nilai pada hasil path coefficient sebagai dasar. Pengujian Prosedur bootstrapping pada SEMPLS dilakukan untuk melihat hasil estimasi dari koefisien jalur beserta tingkat signifikansinya yang selanjutnya dapat digunakan untuk menguji hipotesis yang digunakan pada penelitian. Hipotesis dapat diterima apabila nilai $t$-statistic dari uji bootstrapping berada diantara $\pm 1,96$. Jika $t$ statistic > 1,96, maka hipotesis diterima. Namuun, apabila nilai $t$-statistic $\geq 1,96$, maka hipotesis akan ditolak. Nilai t-Tabel ditentukan dengan signifikansi 5 persen atau
0,05. Semua koefisien jalur pada Tabel 12 memiliki nilai $t$-statistic diatas 1,96 , sehingga dinyatakan memiliki pengaruh yang signifikan.

Berdasarkan data dari Tabel 12 menunjukkan bahwa pengaruh langsung social media marketing terhadap repeat purchase yaitu sebesar 0,271, pengaruh langsung social media marketing terhadap brand image yaitu sebesar 0,670, pengaruh langsung brand image terhadap repeat purchase yaitu sebesar 0,438 dengan masingmasing nilai $t$-statistic sudah lebih besar dari 1,96 dan $p$ value lebih kecil dari 0,05 yang 
menunjukan bahwa pengaruhnya adalah positif dan signifikan.

Pengaruh tidak langsung dalam penelitian ini adalah peran brand image memediasi pengaruh social media marketing terhadap repeat purchase. Besarnya pengaruh tidak langsung pada penelitian ini adalah 0,293, dengan t-statistic sebesar 3,657 dan nilai $p$ value sebesar 0,000 . Sehingga dapat disimpulkan bahwa brand image memediasi pengaruh social media marketing terhadap repeat purchase secara positif dan signifikan.

Pengaruh total hubungan antara social media marketing terhadap repeat purchase sebesar 0,564 dengan t-statistic sebesar 7,104. Nilai ini lebih besar dari pada nilai t-statistic hubungan antara social media marketing terhadap repeat purchase pada pengaruh langsung yakni sebesar 2,167. Jadi variabel brand image berhasil mediasi hubungan antara social media marketing terhadap repeat purchase secara parsial. Pengaruh social media marketing terhadap brand image sebesar 0,670 dengan t-statistic sebesar 12,622. Pengaruh brand image terhadap repeat purchase sebesar 0,438 dengan $t$ statistic sebesar 4,061. Masing-masing konstruk memiliki nilai $p$ value kurang dari 0,50 . Hal ini menyatakan adanya pengaruh yang positif dan signifikan terhadap masingmaing konstruk.

Estimasi model struktual pada Tabel 12. yang menunjukkan bahwa pengujian $\mathrm{H} 1$ menjelaskan adanya pengaruh yang signifikan antara social media marketing dengan repeat purchase yang ditunjukan dengan nilai $t$ statistic sebesar 2,167 yang artinya lebih besar dari 1,96. Nilai koefisien jalurnya sebesar 0,271 yang berarti bahwa pengaruh antara social media marketing terhadap repeat purchase adalah positif. Sehingga H1 dalam penelitian yang menyatakan bahwa pengaruh social media marketing berpengaruh positif dan signifikan terhadap repeat purchase. Hal tersebut menjelaskan bahwa semakin baik perusahaan memanfaatkan social media marketing maka semakin tinggi repeat purchase pada perusahaan Mie Gacoan. Hasil tersebut sesuai dengan penelitian yang pernah dilakukan oleh Kristiani \& Dharmayanti (2017) terhadap 180 responden yang menyatakan terdapat pengaruh social media marketing secara positif dan signifikan terhadap repeat purchase pada industry fast-food restaurant di Surabaya. Hasil penelitian serupa juga didukung oleh penelitian yang dilakukan oleh Rohani et al., (2020); Imron et al., (2018); Kondippli et al., (2016); Kuspriyono \& Nurelasari (2018); Muchardie et al., (2016); Hatta \& Adrenanus (2019); Rahmadhani \& Ariyanti (2019); Susanti (2021) yang menyatakan bahwa social media marketing berpengaruh positif dan signifikan terhadap repeat purchase.

Estimasi model struktual pada Tabel 12. yang menunjukkan bahwa pengujian $\mathrm{H} 2$ menjelaskan adanya pengaruh yang signifikan antara social media marketing dengan brand image yang ditunjukan dengan nilai $t$-statistic sebesar 12,622 yang artinya lebih besar dari 1,96. Nilai koefisien jalurnya sebesar 0,670 yang berarti bahwa pengaruh antara social media marketing terhadap brand image adalah positif. Sehingga $\mathrm{H} 2$ dalam penelitian yang menyatakan bahwa pengaruh social media marketing berpengaruh positif dan signifikan terhadap brand image. Hal tersebut 
menjelaskan bahwa semakin baik perusahaan memanfaatkan social media marketing maka semakin baik brand image yang dimiliki perusahaan.

Hasil tersebut sesuai dengan penelitian yang pernah dilakukan oleh Anizir \& Wahyuni (2017) terhadap 85 responden yang menyatakan terdapat pengaruh social media marketing berpengaruh positif dan signifikan terhadap brand image pada perguruan tinggi swasta di Kota Serang. Hasil penelitian serupa juga didukung oleh penelitian yang dilakukan oleh Barreda et al. (2020); Bilgin (2018); Budiman (2021); Fahmi et al., (2020); Farizan et al., (2019); Kondippli et al., (2016); Kristiani \& Dharmayanti (2017); Muchardie et al., (2016) yang menyatakan bahwa social media marketing berpengaruh positif dan signifikan terhadap brand image.

Estimasi model struktual pada Tabel 12. yang menunjukkan bahwa pengujian $\mathrm{H} 3$ menjelaskan adanya pengaruh yang signifikan antara brand image dengan repeat purchase yang ditunjukan dengan nilai t-statistic sebesar 4,061 yang artinya lebih besar dari 1,96. Nilai koefisien jalurnya sebesar 0,438 yang berarti bahwa pengaruh antara brand image terhadap repeat purchase adalah positif. Sehingga H3 dalam penelitian yang menyatakan bahwa pengaruh brand image berpengaruh positif dan signifikan terhadap repeat purchase. Hal tersebut menjelaskan bahwa semakin baik perusahaan meningkatan brand image maka semakin tinggi repeat purchase pada perusahaan.

Hasil tersebut sesuai dengan penelitian yang pernah dilakukan oleh Pamungkas \& Widodo (2018) terhadap 100 responden yang menyatakan terdapat pengaruh brand image secara positif dan signifikan terhadap repeat purchase product Pertamax Turbo (RON 98). Hasil penelitian serupa juga didukung oleh penelitian yang dilakukan oleh Desi et al., (2017); Efendi et al., (2017); Fahmi (2018); Farizan et al., (2019); Kristiani \& Dharmayanti (2017); Poutrack \& Softic, (2019); Puspitasari et al., (2018); Ramadhan \& Santosa (2017); Semuel \& Wibisono (2019); Subaebasni et al., (2019); Wijaya \& Astuti (2018); Yunaida (2017) yang menyatakan bahwa brand image berpengaruh positif dan signifikan terhadap repeat purchase.

Tabel 13.

Hasil Uji Pengaruh Langsung, Pengaruh Tidak Langsung dan Pengaruh Total

\begin{tabular}{|c|c|c|c|c|}
\hline $\begin{array}{c}\text { Tipe } \\
\text { Pengaruh } \\
\end{array}$ & Variabel & $\begin{array}{c}\text { Standar } \\
\text { Extimates }\end{array}$ & $\begin{array}{c}\text { T-Statistic } \\
(|O / S T D E V|)\end{array}$ & $P$ Values \\
\hline \multirow{3}{*}{$\begin{array}{l}\text { Pengaruh } \\
\text { Langsung }\end{array}$} & Social Media Marketing $(\mathrm{X}) \rightarrow$ Repeat Purchase $\left(\mathrm{Y}_{1}\right)$ & 0,271 & 2,167 & 0,031 \\
\hline & Social Media Marketing $(\mathrm{X}) \rightarrow$ Brand Image $\left(\mathrm{Y}_{2}\right)$ & 0,670 & 12,622 & 0,000 \\
\hline & Brand Image $\left(\mathrm{Y}_{2}\right) \rightarrow$ Repeat Purchase $\left(\mathrm{Y}_{1}\right)$ & 0,438 & 4,061 & 0,000 \\
\hline $\begin{array}{l}\text { Pengaruh } \\
\text { Tidak } \\
\text { Langsung }\end{array}$ & $\begin{array}{l}\text { Social Media Marketing }(\mathrm{X}) \rightarrow \text { Brand Image }\left(\mathrm{Y}_{2}\right) \rightarrow \\
\text { Repeat Purchase }\left(\mathrm{Y}_{1}\right)\end{array}$ & 0,293 & 3,657 & 0,000 \\
\hline \multirow{3}{*}{$\begin{array}{l}\text { Pengaruh } \\
\text { Total }\end{array}$} & Social Media Marketing $(\mathrm{X}) \rightarrow$ Repeat Purchase $\left(\mathrm{Y}_{1}\right)$ & 0,564 & 7,104 & 0,000 \\
\hline & Social Media Marketing $(\mathrm{X}) \rightarrow$ Brand Image $\left(\mathrm{Y}_{2}\right)$ & 0,670 & 12,622 & 0,000 \\
\hline & Brand Image $\left(\mathrm{Y}_{2}\right) \rightarrow$ Repeat Purchase $\left(\mathrm{Y}_{1}\right)$ & 0,438 & 4,061 & 0,000 \\
\hline
\end{tabular}

Sumber: Data diolah, 2021 
Estimasi model struktual pada Tabel 13. pada pengaruh tidak langsung antara social media marketing, brand image, dan repeat purchase didapatkan nilai $t$-satistic sebesar 3,657 yang artinya lebih besar dari 1,96, dan $p$ value sebesar 0,000 yang artinya lebih kecil dari 0,05 yang menunjukkan bahwa variabel brand image mampu memediasi secara parsial hubungan antara social media marketing terhadap repeat purchase. Hal ini sesuai dengan $\mathrm{H} 4$ yang menyatakan bahwa brand image memediasi pengaruh social media marketing terhadap repeat purchase. Hasil ini menjelaskan bahwa semakin baik perusahaan melakukan social media marketing maka semakin tinggi repeat purchase pada perusahaan, maka dari itu perlu adanya brand image perusahaan yang baik dibenak konsumen. Strategi tersebut bisa membuat suatu usaha dapat mempertahankan loyalitas konsumennya dan mampu meningkatkan terjadinya repeat purchase. Hasil tersebut sesuai dengan penelitian yang pernah dilakukan oleh Kristiani \& Dharmayanti (2017); Fahmi et al., (2020) yang menyatakan bahwa brand image mampu memediasi pengaruh social media marketing terhadap repeat purchase

Hasil dari penelitian ini telah mampu memperkaya teori perilaku konsumen yaitu social media marketing dan repeat purchase. Penelitian ini telah mampu menambah kajian empiris, memperkuat penelitian sebelumnya, dan mengkonfirmasi adanya pengaruh brand image memediasi social media marketing terhadap repeat purchase. Berdasarkan hasil penelitian ini digunakan sebagai masukan bagi para pelaku usaha Mie Gacoan sehingga dapat meningkatkan kinerja serta profit dari usaha yang dijalani dengan memperlihatkan beberapa hal seperti pemahaman mengenai social media marketing oleh pelaku Mie Gacoan di Kota Denpasar sangat penting. Berdasarkan hasil penelitian ini Mie Gacoan di Kota Denpasar telah melakukan social media marketing dengan cara membuat konten sosial media seperti foto, video yang berisikan informasi lengkap untuk para konsumennya. Sosial media juga dapat dimanfaatkan sebagai penghubung dengan konsumen dan sarana promosi agar bisa meningkatkan terjadinya pembelian berulang dari para konsumen. Selain itu meningkatkan brand image sangat penting bagi Mie Gacoan di Kota Denpasar karena berdasarkan hasil penelitian ini produk Mie Gacoan memiliki kualitas dan desain yang baik, serta memiliki cabang yang dapat dengan mudah diketahui oleh konsumennya. Hal ini bertujuan untuk menarik minat pelanggan untuk kembali melakukan pembelian ulang.

\section{SIMPULAN DAN SARAN}

Berdasarkan hasil analisis penelitian maka simpulan dari penelitian ini adalah social media marketing berpengaruh secara positif dan signifikan terhadap repeat purchase Mie Gacoan di Kota Denpasar. Hal ini menunjukkan bahwa semakin baik social media marketing yang dilakukan Mie Gacoan maka repeat purchase semakin tinggi. Social media marketing berpengaruh secara positif dan signifikan terhadap brand image Mie Gacoan di Kota Denpasar. Hal ini menunjukkan bahwa semakin baik social media marketing yang dilakukan Mie Gacoan 
maka brand image semakin baik. Brand image berpengaruh seacara positif dan signifikan terhadap repeat purchase Mie Gacoan di Kota Denpasar. Hal ini menunjukkan bahwa semakin baik brand image yang dimiliki oleh Mie Gacoan maka repeat purchase semakin tinggi. Brand image mampu memediasi secara positif dan signifikan pengaruh social media marketing terhadap repeat purchase Mie Gacoan di Kota Denpasar. Hal ini menunjukkan bahwa brand image mampu memperkuat pengaruh social media marketing terhadap repeat purchase.

Berdasarkan hasil penelitian yang dilakukan maka penulis memberikan saran yakni pertama, bagi pihak Mie Gacoan di Kota Denpasar, diharapkan dapat meningkatkan penggunaan social media marketing sebagai tempat untuk membangun komunitas dan bertukar informasi dengan para pelanggan. Hal ini akan membangun hubungan yang baik antara Mie Gacoan di Kota Denpasar dengan para pelanggannya, sehingga para pelanggan akan datang lagi untuk melakukan pembelian dimasa yang akan datang. Kedua, secara keseluruhan penilaian responden yang terendah berada pada pernyataan brand image mengenai mengkonsumsi logo Mie Gacoan dapat dengan mudah diketahui oleh konsumennya. Informasi ini dapat dijadikan sebagai acuan pihak Mie Gacoan di Kota Denpasar untuk meningkatkan brand image dalam mempromosikan Mie Gacoan di Kota Denpasar, sehingga konsumen akan dengan mudah mengetahui Mie Gacoan dan dengan demikian konsumen akan mungkin untuk melakukan pembelian kembali di masa yang akan datang. Ketiga, bagi peneliti selanjutnya diharapkan dapat melakukan penelitian dengan cakupan yang lebih luas, dan meneliti ataupun menambah variabel diluar penelitian ini yang yang memang memiliki pengaruh terhadap repeat purchase perusahaan. Variabel lainnya dapat berupa brand trust atau customer intention. Selain itu, penelitian selanjutnya juga dapat menggunakan objek yang lain selain Mie Gacoan. Misalnya restoran jepang, china, korea bahkan western restaurant, selain itu bisa juga menggunakan café ataupun fashion product.

Berdasarkan penelitian yang telah dilakukan ditemukan beberapa keterbatasan dalam penelitian ini yakni pertama, penelitian ini hanya dilakukan pada pelanggan Mie Gacoan di Kota Denpasar, yakni pada konsumen Mie Gacoan Panjer, Mie Gacoan Teuku Umar Barat, Mie Gacoan Gatsu Tengah, dan Mie Gacoan Renon, sehingga tidak dapat digeneralisasikan. Kedua, data dalam penelitian ini diambil dalam satu titik waktu tertentu (cross section), sementara lingkungan selalu mengalami perubahan sehingga penelitian yang sama perlu dilakukan kembali dimasa yang mendatang.

\section{REFERENSI}

Anizir, \& Wahyuni, R. (2017). Pengaruh Sosial Media Marketing Terhadap Brand Image Perguruan Tinggi Swasta di Kota Serang. Jurnal Sains Manajemen, 3(2), 1-14.

Azryantiti, T. (2019). 6 Makanan Buat Kamu yang Mau Libur Akhir Tahun di Bali, Udah Coba? Idntimes.Com.https://www.idntimes.com/food /dining-guide/grabfood/rekomendasimakanan-di-bali-csc/6

Barreda, A. A., Nusair, K., Wang, Y., Okumus, F., \& Bilgihan, A. (2020). The impact of social media activities on brand image and 
Peran Brand Image Memediasi Pengaruh...

Ni Luh Widya Uttari \& I Gusti Ayu Ketut Giantari

emotional attachment: A case in the travel context. Journal of Hospitality and Tourism Technology, 11(1), 109-135.

Bilgin, Y. (2018). The Effect Of Social Media Marketing Activities on Brand Awareness, Brand Image and Brand Loyalty. Business \& Management Studies: An International Journal, 6(1), 128-148.

Budiman, S. (2021). The Effect of Social Media on Brand Image and Brand Loyalty in Generation Y. Journal of Asian Finance, Economics and Business, 8(3), 1339-1347.

Desi, Bahri, S., \& Ponirin. (2017). Pengaruh Citra Merek Dan Pengetahuan Produk Terhadap Keputusan Pembelian Ulang Air Mineral Cleo Di Alfamidi Kota Palu. Jurnal Ilmu Manajemen Universitas Tadulako (JIMUT), 3(2), 145-150.

Efendi, Z., Widyaningrum, M. E., \& Imamah, N. (2017). Pengaruh Promosi, Citra Merek, dan Kepuasan Konsumen Terhadap Pembelian Berulang Produk Elzatta di Surabaya. Jurnal Manajemen Branchmark, 3(3), 1097-1109.

Fahmi, M. (2018). The Influence of Quality of Service, Relational Marketing and Corporate Image against The Loyalty of Suppliers in PT Raja Putra Manggala. International Conference of ASEAN Prespective and Policy (ICAP), 1(1), 377-385.

Fahmi, M., Arif, M., Farisi, S., \& Purnama, N. I. (2020). Peran Brand Image dalam Memediasi Pengaruh Social Media Marketing terhadap Repeat Purchase pada Fast-Food Restaurant di Kota Medan. Jurnal Samudra Ekonomi Dan Bisnis, 11(1), 53-68.

Farizan, N., Rohman, F., \& Hussein, A. S. (2019). Customer Satisfaction As Mediation. Journal of Applied Management (JAM), 17(1), 127132.

Ghozali, I. (2014). Structural Equation Modeling. Metode Alternatif dengan Partial Least Squares (PLS). Semarang: Badan Penerbit Universitas Diponogoro.

Hardilawati, W. laura. (2020). Strategi Bertahan UMKM di Tengah Pandemi Covid-19. Jurnal Akuntansi Dan Ekonomika, 10(1), 89-98.

Hasan, A. (2013). Marketing (Cetakan Pe). Yogjakarta: Media Pressindo.

Hatta, H., \& Adrenanus, R. (2019). Pengaruh Influencer, Membership Program, dan Instagram Ads Terhadap Minat Pembelian Ulang Customer Brand Coach. (Studi Kasus Coach, Plaza Senayan ). Journal of
Entrepreneurship Management and Industry (JEMI), 2(2), 79-89.

Imron, ahmad syaifulloh, Wardani, niken hendrakusma, \& Rokhmawati, retno indah. (2018). Analisis Pengaruh Pemasaran Media Sosial Terhadap Loyalitas Konsumen: Studi Pada Transportasi Online (Go-Jek Indonesia). Jurnal Pengembangan Tekonologi Informasi Dan Ilmu Komputer, 2(9), 2570-2578.

Jokinen, T. (2016). Brand in Social Media and The Impact of Social Media on Brand Image. (Thesis). South Ostrobothnia: Seinäjoki University Of Applied Sciences.

Khasanah, M. A., Wihara, D. S., \& Batu, A. P. (2020). Cahaya aktiva. Cahaya Aktiva (Jurnal Ekonomu, Manajemen Dan Akuntansi, 10(2), 183-196.

Kondippli, G., Jayawicakrama, M., Yugandari, O., Pamudini, S., \& Samarasinghe, H. (2016). The Influence of Social Media Marketing on Customer Loyalty towards Clothing Stores. Conference: National Conference on Technology and Management, 59-68.

Kotler, P., \& Keller, K. (2016). Marketing Management (15 Edition). Boston: Pearson Education.

Kristiani, P., \& Dharmayanti, D. (2017). Pengaruh Social Media Marketing terhadap Repeat Purchase dengan Variabel Intervening Perceived Service Quality dan Brand Image pada Industri Fast-Food Restaurant di Surabaya. Petra Business \& Management Review, 3(1), 67-84.

Kurniawan, A. (2021). Tren Belanja Online Selama Pandemi, Barang Apa yang Banyak Dibeli Masyarakat? Kompas.Com. https://money.kompas.com/read/2021/06/24/1 11700226/tren-belanja-online-selamapandemi-barang-apa-yang-banyak-dibelimasyarakat-

Kuspriyono, T., \& Nurelasari, E. (2018). Pengaruh Social Media Marketing Terhadap Customer Bonding dan Purchase to Intention. Cakrawala, 18(2), 235-242.

Maulani, L. S., \& Sanawiri, B. (2019). Pengaruh Social Media Marketing Terhadap Brand Awareness Serta Dampaknya Pada Purchase Decision (Survei Online pada Followers Aktif Instagram dan Facebook Vauza Tamma Hijab). Jurnal Administrasi Bisnis (JAB), 72(2), 148-156.

Mileva, L., \& Fauzi, A. (2018). Pengaruh Social Media Marketing Terhadap Keputusan Pembelian 
Peran Brand Image Memediasi Pengaruh...

Ni Luh Widya Uttari \& I Gusti Ayu Ketut Giantari

(Survei Online pada Mahasiswa Sarjana Jurusan Ilmu Administrasi Bisnis Angkatan 2014/2015 Fakultas Ilmu Administrasi Universitas Brawijaya yang Membeli Starbucks Menggunakan LINE). Jurnal Administrasi Bisnis (JAB), 58(1), 190-199.

Muchardie, B. G., Yudiana, N. H., \& Gunawan, A. (2016). Effect of Social Media Marketing on Customer Engagement and its Impact on Brand Loyalty in Caring Colours Cosmetics, Martha Tilaar. Binus Business Review, 7(1), $83-87$.

Nurlaily, I., Noermijati, \& Hussein, A. (2017). Influence of Life Style and Attitude Toward Trust and Repeat Purchase Intentions on Social Media Users (Study On Instagram Users in Malang). Wacana, 20(2), 68-78.

Pamungkas, A. D., \& Widodo, A. (2018). Pengaruh Brand Image Terhadap Keputusan Pembelian Ulang Green Product Pertamax Turbo (RON98) dengan Kepuasan Konsumen Sebagai Variabel Intervening. E-Proceeding of Management, 5(2), 2584-2592.

Pinto, M. B., \& Yagnik, A. (2016). Fit for life: A content analysis of fitness tracker brands use of Facebook in social media marketing. Journal of Brand Management, 24(1), 49-67.

Poutrack, M., \& Softic, S. (2019). Influence of Social Media Content on Consumer Purchase Intention: Mediation Effect of Brand Equity. Eurasian Journal of Business and Economics, 12(23), 17-43.

Pratiwi, A. A. M. (2021). Peran Media Sosial Dalam Meningkatkan Penjualan Online Saat Pandemi Covid-19. Jurnal Ilmiah Satyagraha, 3(2), $73-81$.

Puspitasari, Eka, Di., \& Nailis, W. (2018). Pengaruh Lokasi dan Citra Merek Terhadap Keputusan Pembelian Konsumen (Studi Kasus Pada Konsumen KFC Dermaga Point Palembang). Jembatan, 15(1), 23-32.

Rahmadhani, S. W., \& Ariyanti, M. (2019). Pengaruh Sosial Media Marketing Instagram Terhadap Repurchase Intention pada Konsumen Wardah. E-Proceeding of Management, 6(2), 2751-2760.

Ramadhan, A. G., \& Santosa, S. B. (2017). Analisis Pengaruh Kualitas Produk, Kualitas Pelayanan, dan Citra Merek terhadap Minat Beli Ulang pada Sepatu Nike Running di Semarang melalui Kepuasan Pelanggan sebagai Variabel Intervening. Diponegoro Journal of Management, 6(1), 1-12.
Rohani, S., Hufron, M., \& Rizal, M. (2020). Pengaruh Media Sosial dan Celebrity Endoser Terhadap Minat Beli Ulang dengan Brand Trust Sebagai Variabel Intervening. E-Jurnal Riset Manajemen Prodi Manajemen FEB UNISMA, 09(10), 48-65.

Semuel, H., \& Wibisono, J. (2019). Brand Image, Customer Satisfaction Dan Customer Loyalty Jaringan Supermarket Superindo Di Surabaya. Jurnal Manajemen Pemasaran, 13(1), 27-34.

Setiadi, N. J. (2015). Perilaku Konsumen. Jakarta: Kencana Prenadamedia.

Subaebasni, Henny, R., \& A.R. Arie, W. (2019). Effect of Brand Image, the Quality and Price on Customer Satisfaction and Implications for Customer Loyalty PT Strait Liner Express in Jakarta. International Review of Management and Marketing, 9(1), 90-97.

Sudaryono. (2016). Manajemen Pemasaran, Teori dan Implementasi. Yogjakarta: ANDI.

Sugiyono. (2018). Metode Penelitian Manajemen. Bandung: Alfabeta.

Suryani, S., \& Rosalina, S. S. (2019). Pengaruh Brand Image, Brand Trust, dan Kualitas Layanan Terhadap Keputusan Pembelian Ulang Dengan Kepuasan Konsumen Sebagai Variabel Moderating (Studi pada Startup Business Unicorn Indonesia). Journal of Business Studies, 04(1), 41-53.

Susanti, D. (2021). Digital Marketing pada Customer Value Dan Customer Engagement Terhadap Repeat Purchase pada Marketplace. SULTANIST: Jurnal Manajemen Dan Keuangan, 9(2), 134-146.

Venessa, I., \& Arifin, Z. (2017). Pengaruh Citra Merek (Brand Image dan Harga Terhadap Keputusan Pembelian Konsumen (Survei pada Mahasiswa Program Studi Administrasi Bisnis Fakultas Ilmu Administrasi Universitas Brawijaya Malang Tahun Angkatan 2013 / 2014 dan 2014 / 2015 Pengguna Kartu Pr. Jurnal Administrasi Bisnis, 51(1), 44-48.

Wijaya, H. R., \& Astuti, S. R. T. (2018). The Effect of Trust and Brand Image to Repurchase Intention in Online Shopping. KnE Social Sciences, 3(10), 915-928.

Wijaya, P. E. S. A., \& Suparna, G. (2017). Peran Customer Satisfaction Memediasi Pengaruh Experiential Marketing Terhadap Repeat Purchase pada Mangsi Coffee di Denpasar. EJurnal Manajemen Universitas Udayana, 6(10), 5432-5459.

Yazdanparast, A., Joseph, M., \& Muniz, F. (2016). 
Peran Brand Image Memediasi Pengaruh... Ni Luh Widya Uttari \& I Gusti Ayu Ketut Giantari

Consumer Based Brand Equity in The 21st Century: an Examination of the Role of Social Media Marketing. Young Consumers, 17(3), 15-28.

Yunaida, E. (2017). Pengaruh Brand Image (Citra Merek) terhadap Loyalitas Konsumen Produk Oli Pelumas Evalube di Kota Langsa. Jurnal Manajemen Dan Keuangan, 6(2), 798-807. 